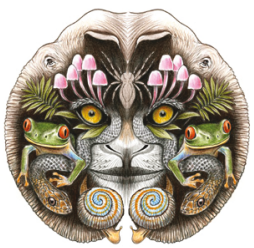

ISSN

Online 0974-7907

Print 0974-7893

OPEN ACCESS

\title{
NEW RECORDS OF DRAGONFLIES AND DAMSELFLIES (INSECTA: ODONATA) FROM THE WESTERN GHATS OF MAHARASHTRA, INDIA
}

\author{
Pankaj Koparde ${ }^{1}$, Prachi Mhaske ${ }^{2}$ \& Ankur Patwardhan ${ }^{3}$
}

1,2,3 Department of Biodiversity, MES's Abasaheb Garware College, Karve Road, Pune, Maharashtra 411004, India ${ }^{1}$ pankajkoparde@gmail.com (corresponding author), 2 prachi.mhaske13@gmail.com, ${ }^{3}$ ankurpatwardhan@gmail.com

Abstract: Odonates were surveyed across 10 localities from Western Ghats of Maharashtra State, India during 2011-2013. We recorded 64 species belonging to 40 genera and 12 families. Seven species are new records for the region, and four out of them are new records for Maharashtra State. In this paper, we discuss these species records and their micro-habitats, and update previous knowledge on distribution of odonates.

Keywords: Distribution, ecological indicator, micro-habitat, northern Western Ghats, Odonata.

Odonates (dragonflies and damselflies) are freshwater insects, often used as indicator taxa in biodiversity studies (Subramanian 2005; Córdoba-Aguilar 2008; Subramanian et al. 2008). Records of these insects on a spatiotemporal scale are useful to understand microhabitat quality and/or land-use change. Although it is relatively difficult to identify odonates on field, availability of photographic field-guides (Emiliyamma et al. 2005; Subramanian 2005; Andrew et al. 2008; Nair 2011; Kiran \& Raju 2013), web-portals (Asia Dragonfly 2014), blogs and forums (DragonflyIndia 2014) have made it an easier task. As a consequence, more and more people are now getting interested in recording species from different regions across India.

Western Ghats of India and Sri Lanka, one of the global biodiversity hotspots (Myers et al. 2000), are known to support number of Odonata species. Around 174 species have been recorded from Western Ghats of India alone, comprising 56 endemics to the region (Subramanian et al. 2011). Although Odonata fauna of Western Ghats is well-documented (Fraser 1924, 1932, 1933, 1934, 1936; Emiliyamma \& Radhakrishnan 2000, 2002; Radhakrishnan \& Emiliyamma 2003; Emiliyamma 2005; Subramanian \& Sivaramkrishan 2005; Subramanian 2007; Rangnekar et al. 2010; Subramanian et al. 2011; Emiliyamma et al. 2012; Das et al. 2013; Emiliyamma et al. 2013; Kulkarni \& Subramanian 2013; Subramanian et al. 2013; Rangnekar \& Naik 2014), certain parts are still under-explored. The northern Western Ghats (Gujarat, Maharashtra, Goa, and northwestern Karnataka) are one of the under-explored areas in terms of documentation of Odonata fauna. These areas are characterized by highly fragmented forest cover. Most of the Western Ghats endemic odonates are known to be associated with closed forested areas with streams (Subramanian et al. 2011). Such habitats are often

DOI: http://dx.doi.org/10.11609/JoTT.o3402.5744-54 | ZooBank: urn:Isid:zoobank.org:pub:6A4BE843-51F8-4E5A-A89F-07F9A13209B8

Editor: K.A. Subramanian, Zoological Survey of India, Kolkata, India.

Date of publication: 26 May 2014 (online \& print)

Manuscript details: Ms \# 03402 | Received 07 November 2012 | Final received 15 May 2014 | Finally accepted 16 May 2014

Citation: Koparde, P., P. Mhaske \& A. Patwardhan (2014). New records of dragonflies and damselflies (Insecta: Odonata) from the Western Ghats of Maharashtra, India. Journal of Threatened Taxa 6(5): 5744-5754; http://dx.doi.org/10.11609/JoTT.03402.5744-54

Copyright: @ Koparde et al. 2014. Creative Commons Attribution 4.0 International License. JoTT allows unrestricted use of this article in any medium, reproduction and distribution by providing adequate credit to the authors and the source of publication.

Funding: Indian Space Research Organization under ISRO-UoP interaction program (2011-2013).

Competing Interest: The authors declare no competing interests.

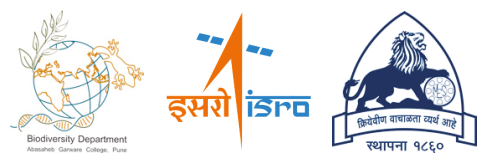

Acknowledgements: The present study was supported under the ISRO-UOP initiative. We thank Dr. M.C. Uttam, Director, ISRO-UoP for his encouragement and Dr. K.A. Subramanian, ZSI-Kolkata who was always helpful in confirming the identification of the specimens. We also thank the Principle Chief Conservator of Forests (Territorial and Wildlife wing), Maharashtra. Personal thanks are also due to Mr. Mohan Karnat, CF (WL), Kolhapur, Mr. Zure (ACF, Chandoli NP), Mr. Mane (RFO, Chandoli NP), and Mr. Nikam (RFO, Patan) and other ground level forest department staff for their help. We also thank the Principal, Abasaheb Garware College, Pune, for his support. Field level support and assistance from Ms. Apoorva Sahastrabuddhe, Mr. Rakesh Deulkar, Mr. Abhishek Narvekar, Ms. Priti Bangal, Ms. Monali Mhaskar, Ms. Prajakta Pathare, Mrs. Medhavi Tadwalkar-Rajwade, Ms. Amruta Joglekar is gratefully acknowledged. We also thank the anonymous referees for their critical comments. 
good quality forested areas. Therefore, documenting fauna from such regions is highly important as it helps fill the knowledge gap about distribution of species, which may have conservation implications. Odonata fauna of northwestern Karnataka and Goa is relatively well-explored (Prasad 1995; Subramanian 2007; Kulkarni \& Talmale 2008; Subramanian et al. 2008; Yadav et al. 2008; Rangnekar et al. 2010; Subramanian et al. 2013; Rangnekar \& Naik 2014) as compared to Maharashtra and Gujarat; however the region still lacks considerable data on spatial distribution and diversity of odonates. As per Kulkarni et al. (2012), 101 Odonata species have been reported from Maharashtra; however, very few studies have looked into Odonata fauna of Western Ghats of Maharashtra (WGM) (Fraser 1924, 1933, 1934, 1936; Aland et al. 2012; Sathe \& Bhusnar 2010; Kulkarni \& Subramanian 2013). According to Fraser (1924, 1933, 1934, 1936); Subramanian (2005); Rangnekar et al. (2010) and Rangnekar \& Naik (2014); northern distributional limit of many Western Ghats endemic species has been reported to be either south-west Maharashtra or northern Goa. However this is most probably an artefact of sampling. To explore possibility of finding endemic species of conservation concern in southwestern and centralwestern Maharashtra, we carried out a survey of odonates. This paper updates knowledge on the distribution of odonates, partially documents morphological data, and comments on spatial distribution of the species and threats associated with them.

\section{Materials and Methods}

Study area: The study area falls in central-west and south-west Maharashtra. The study area includes Sahyadri Tiger Reserve (STR), a recently declared tiger reserve which lies between $17.33^{\prime}-17.83^{\prime} \mathrm{N} \& 73.58^{\prime}-$ 73.875'E, Amboli (15.964722'N \& 74.003567'E, 787m), Parpoli $\left(15.950389^{\prime} \mathrm{N} \& 73.958056^{\prime} \mathrm{E}, 130 \mathrm{~m}\right)$ and Verle $(15.987639 ' \mathrm{~N}$ \& 73.970472' $\mathrm{E}, 754 \mathrm{~m})$ villages. The crow-flight distance between STR and localities in and around Amboli is around $128 \mathrm{~km}$ (Google Inc. 2013). STR lies in centralwestern Maharashtra; whereas Amboli, Parpoli and Verle are from southwestern Maharashtra. Administrative boundary of STR is spread across Satara, Sangli, Kolhapur and Ratnagiri districts, and comprises of Koyna Wildlife Sanctuary (Koyna WS), Chandoli National Park (Chandoli NP) and corridor joining both these protected areas. Amboli, Parpoli and Verle villages are a part of Sindhudurg District of Maharashtra. The landscape of STR is patchy in terms of forest cover and mainly consists of moist-deciduous to evergreen forests. Six localities from STR, one from Koyna WS and corridor area each and four from Chandoli NP were studied during the survey (Fig. 1). The landscape of Amboli, Parpoli and Verle villages is mainly composed of semi-evergreen forests. A number of perennial streams flow across these

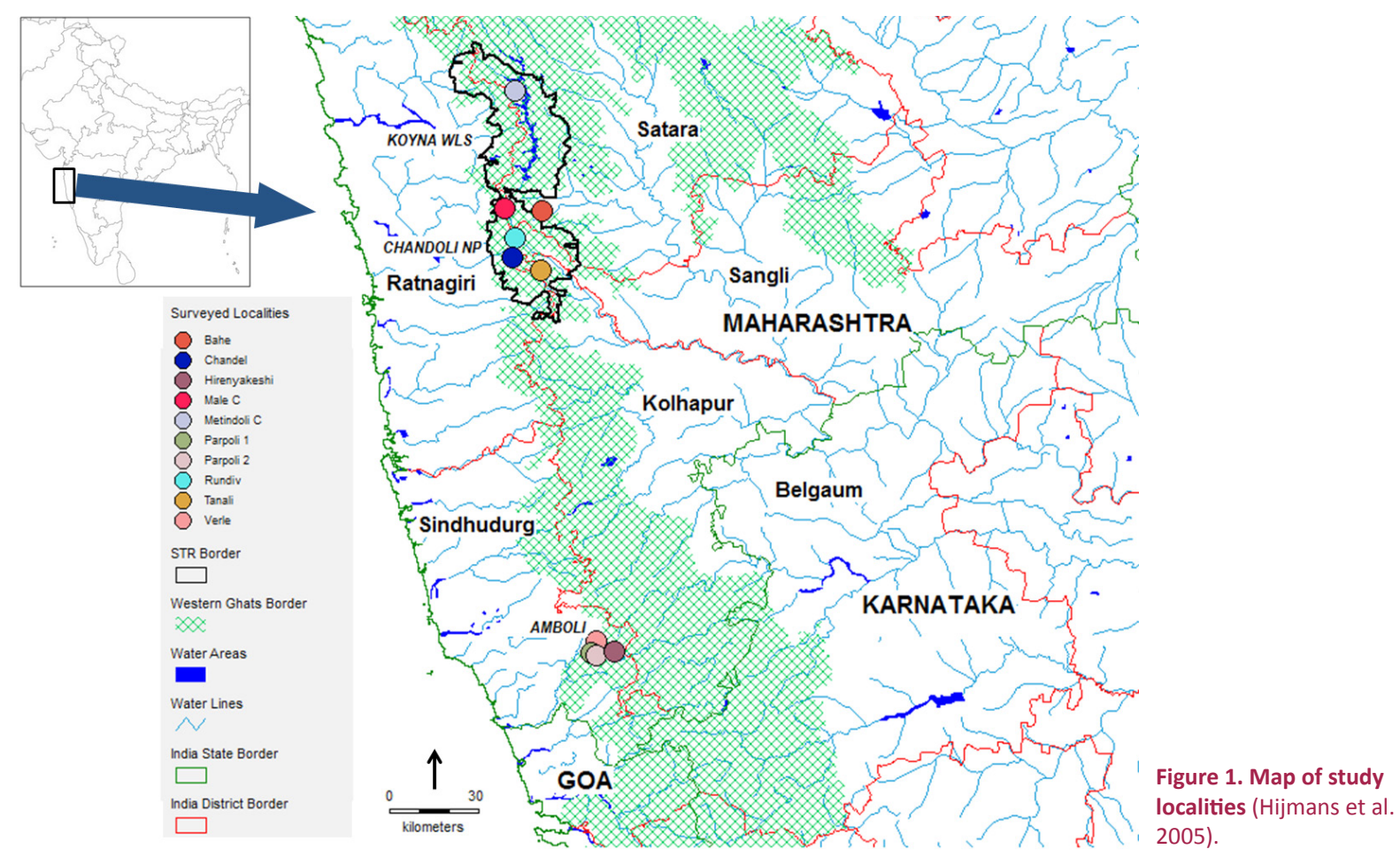


villages passing through a variety of land-use, offering ideal habitats for odonates. The temperature range of the study area is between $13-35{ }^{\circ} \mathrm{C}$. The study area experiences three distinct seasons-summer (FebruaryJune), monsoon (July-August), winter (SeptemberJanuary). Hiranyekeshi River in Amboli, two streams in Parpoli Village of which one flows across agricultural land (Parpoli 1) and the other across moist deciduous forest (Parpoli 2), and an open stream that flows nearby Verle Village (Fig. 1) were surveyed.

Data collection: Odonates were recorded opportunistically during October 2011 to April 2013. Species were recorded during random walks along streams, and shores of water-reservoirs and rivers between 0800-1300hr. Sampling was carried out throughout the year, except during monsoon. A $8 \times 40$ binocular was used to observe the insects. Individual records were geo-referenced using a Garmin GPS Map 60. Odonates were identified using field guides (Subramanian 2005; Nair 2011) and taxonomy monographs (Fraser 1933, 1934, 1936). Web-forums (Asia-dragonfly 2014; Dragonflyindia 2014) were accessed for finding spatial data in public domain. Scientific names and authorities follow Subramanian (2009). For records from Maharashtra, Fraser (1924, 1932) and reviews by Tiple (2012) and Kulkarni et al. (2012) were consulted. Photographs of wing venation and anal appendages were taken for specimens, which were difficult to identify on field. No specimens were collected except for two species, viz., Protosticta hearseyi Fraser, 1922 (single male) and Coorg Bambootail Caconeura ramburi Fraser, 1922 (single female). Both the specimens were hand-picked and dry preserved to confirm the identification by using stereoscopy. The specimens were sent to Zoological Survey of India, Calcutta for identification confirmation. Measurements were taken using a digital vernier calliper.

\section{Results}

1. Odonata fauna of the study area: Sixty-four species belonging to 40 genera, spread across 12 families were recorded during the survey (Annexure 1). Sub-order Anisoptera was represented by 38 species, and 26 species represented sub-order Zygoptera. Libellulidae was the best represented family followed by Coenagrionidae and Aeshnidae. The list contains seven new spatial records for WGM, which include four Zygopteran members, viz., P. hearseyi, C. ramburi, Malabar Torrent-Dart Euphaea fraseri (Laidlaw, 1920) and Yellow-striped Blue-Dart Pseudagrion indicum Fraser, 1924, and three Anisopteran members, viz., Blue Hawklet Hylaeothemis indica Fraser,
1943, Nilgiri Clawtail Onychogomphus nilgiriensis Fraser, 1922 and Indian Lyretail Heliogomphus promelas (Selys, 1873). Out of these seven, four species are new records for Maharashtra State. The list contains two Near Threatened species, viz., Heliogomphus promelas and Blue Ground-Skimmer Indothemis carnatica (Fabricius, 1798).

\section{Field notes on new species records:}

i. Protosticta hearseyi Fraser, 1922 (Platystictidae): Eight individuals were sighted on a belt-transect of $500 \times 10 \mathrm{~m}$ in moist-deciduous forest of Bahe Village (Table 1, Fig. 1 and Image 1A). All eight individuals were observed to be perched on dry twigs or flying weakly 1-2 $\mathrm{m}$ above ground when disturbed. Eye coloration was blue above and pale blue below separated by horizontal thick brown ring. Pterostigma was dark brown. The collected male specimen showed 17 post-nodal nervures in fore-wings and 15 in hind-wings. Segment (S) eight of abdomen was turquoise blue with a dorsal black stripe dividing the blue patch. Anal appendages were dark brown. Superior anal appendages were typical 'fingerthumb' shaped.

ii. Caconeura ramburi (Fraser, 1922) (Platycnemididae): A single female specimen was sighted at Chandel and Rundiv forest-beats each (Table 1, Fig. 1 , Image 1B). Both individuals were slow moving. In another instance, five individuals, including three males, were recorded on a $500 \times 10 \mathrm{~m}$ belt-transect laid in moistdeciduous forest of Bahe Village (Table 1, Image 1C). Eyes of male specimens were azure blue with a black cap. Abdominal segments were black marked with blue basal rings except for S1, S8 and S9 which were prominently azure blue. Thorax of collected female specimen was greenish yellow marked with black stripes dorsally and laterally, and yellow ventrally. Eyes were dark brown above and greenish laterally and ventrally. The female specimen showed 16-19 post-nodal nervures in forewings and 17-20 post-nodal nervures in hind-wings.

iii. Euphaea fraseri (Laidlaw, 1920) (Euphaeidae): One male and two females were sighted at Chandel forest-beat on a 500×10 m transect (Table 1, Images 1 $D, E)$. All the insects were basking in the sunlight and occasionally darting to catch prey. Male was bright red colored with black patches at the tips of hind wings covering around one fourth area of hind-wings. Eyes were dark brown dorsally and laterally, fading to grey ventrally. The abdomen was bright red except S7-S10 which were black. The females were yellow, with black dorsal streaking on abdomen. S7-S10 were dark brown to black as compared to rest of the segments. Eyes were dark brown above, grey below. Thorax was yellow 
Table 1. Sampling details and ecological parameters across sites

\begin{tabular}{|c|c|c|c|c|c|c|c|c|}
\hline \multirow{2}{*}{ Species } & \multirow{2}{*}{$\begin{array}{l}\text { Date and } \\
\text { Month of } \\
\text { Sampling }\end{array}$} & \multirow{2}{*}{ Location } & \multirow{2}{*}{$\begin{array}{l}\text { Geographic } \\
\text { Co-ordinates }\end{array}$} & \multirow{2}{*}{$\begin{array}{l}\text { Altitude } \\
\text { (in m) }\end{array}$} & \multicolumn{3}{|c|}{ No. of individuals } & \multirow[t]{2}{*}{ Habitat } \\
\hline & & & & & M & $\mathrm{F}$ & Total & \\
\hline $\begin{array}{l}\text { Protosticta hearseyi } \\
\text { Fraser, } 1922\end{array}$ & 1.vii.2012 & Bahe, Satara & $\begin{array}{l}17.308489 ' \mathrm{~N} \\
73.8056566^{\prime} \mathrm{E}\end{array}$ & 940 & 2 & 6 & 8 & $\begin{array}{l}\text { Moist-deciduous forest with lot of } \\
\text { leaf litter and humus }\end{array}$ \\
\hline \multirow{4}{*}{$\begin{array}{l}\text { Caconeura ramburi } \\
\text { Fraser, } 1922\end{array}$} & 21.v.2012 & $\begin{array}{l}\text { Chandel forest-beat, } \\
\text { Chandoli NP }\end{array}$ & $\begin{array}{l}17.1641399^{\prime} \mathrm{N} \\
73.713194 ' \mathrm{E} \\
\end{array}$ & 847 & 0 & 1 & 1 & $\begin{array}{l}\text { Closed stream with semi-evergreen } \\
\text { riparian vegetation }\end{array}$ \\
\hline & 24.v.2012 & $\begin{array}{l}\text { Rundiv forest-beat, } \\
\text { Chandoli NP }\end{array}$ & $\begin{array}{l}17.224139^{\prime} \mathrm{N} \\
73.724028^{\prime} \mathrm{E}\end{array}$ & 848 & 0 & 1 & 1 & $\begin{array}{l}\text { Closed dried stream with semi- } \\
\text { evergreen riparian vegetation }\end{array}$ \\
\hline & 1.vii.2012 & Bahe, Satara & $\begin{array}{l}17.308425^{\prime} \mathrm{N} \\
73.805647^{\prime} \mathrm{E}\end{array}$ & 940 & 3 & 2 & 5 & $\begin{array}{l}\text { Closed stream with moist- } \\
\text { deciduous riparian vegetation }\end{array}$ \\
\hline & 21.iv.2013 & $\begin{array}{l}\text { Chandel beat, } \\
\text { Chandoli NP }\end{array}$ & $\begin{array}{l}17.144361 ' \mathrm{~N} \\
73.7243899^{\prime} \mathrm{E} \\
\end{array}$ & 867 & 0 & 1 & 1 & $\begin{array}{l}\text { Closed stream with moist- } \\
\text { deciduous riparian vegetation }\end{array}$ \\
\hline \multirow{6}{*}{$\begin{array}{l}\text { Euphaea fraseri } \\
\text { Laidlaw, } 1920\end{array}$} & 8.x.2011 & $\begin{array}{l}\text { Hiranyekeshi River, } \\
\text { Amboli }\end{array}$ & $\begin{array}{l}15.955194^{\prime} \mathrm{N} \\
74.0275566^{\prime} \mathrm{E} \\
\end{array}$ & 838 & 1 & 0 & 1 & $\begin{array}{l}\text { River under thick cover of semi- } \\
\text { evergreen vegetation }\end{array}$ \\
\hline & 21.v.2012 & $\begin{array}{l}\text { Chandel forest-beat, } \\
\text { Chandoli NP }\end{array}$ & $\begin{array}{l}17.1641399^{\prime} \mathrm{N}, \\
73.713194^{\prime} \mathrm{E}\end{array}$ & 847 & 1 & 2 & 3 & $\begin{array}{l}\text { Closed stream with semi-evergreen } \\
\text { riparian vegetation }\end{array}$ \\
\hline & 27.v.2012 & $\begin{array}{l}\text { Tanali forest-beat, } \\
\text { Chandoli NP }\end{array}$ & $\begin{array}{l}17.12625^{\prime} \mathrm{N} \\
73.800861^{\prime} \mathrm{E}\end{array}$ & 841 & 1 & 0 & 1 & $\begin{array}{l}\text { Closed dried stream covered with } \\
\text { reeds }\end{array}$ \\
\hline & 27.x.2012 & $\begin{array}{l}\text { Parpoli Stream 1, } \\
\text { Amboli }\end{array}$ & $\begin{array}{l}15.950333^{\prime} \mathrm{N}, \\
73.957861^{\prime} \mathrm{E}\end{array}$ & 95 & 0 & 1 & 1 & $\begin{array}{l}\text { Open stream surrounded by dry- } \\
\text { deciduous forest and paddy-fields }\end{array}$ \\
\hline & 27.x.2012 & $\begin{array}{l}\text { Parpoli Stream 2, } \\
\text { Amboli }\end{array}$ & $\begin{array}{l}15.946028^{\prime} \mathrm{N}, \\
73.973194^{\prime} \mathrm{E}\end{array}$ & 95 & 16 & 1 & 17 & $\begin{array}{l}\text { Open stream surrounded by moist- } \\
\text { deciduous forest }\end{array}$ \\
\hline & 29.x.2012 & Verle, Amboli & $\begin{array}{l}\text { 15.987639'N, } \\
73.970472 \text { ' } \mathrm{n}\end{array}$ & 117 & 0 & 1 & 1 & $\begin{array}{l}\text { Open stream surrounded by moist- } \\
\text { deciduous forest, inactive paddy- } \\
\text { fields and scrubland }\end{array}$ \\
\hline \multirow{5}{*}{$\begin{array}{l}\text { Pseudagrion indicum } \\
\text { Fraser, } 1924\end{array}$} & 8.x.2011 & $\begin{array}{l}\text { Hiranyekeshi River, } \\
\text { Amboli }\end{array}$ & $\begin{array}{l}15.956667 ' \mathrm{~N}, \\
74.022694 \text { ' } \mathrm{E}\end{array}$ & 821 & 2 & 0 & 2 & $\begin{array}{l}\text { Open river surrounded by } \\
\text { semi-evergreen vegetation and } \\
\text { scrubland }\end{array}$ \\
\hline & 29.x.2012 & Verle, Amboli & $\begin{array}{l}15.987639^{\prime} \mathrm{N} \\
73.970472^{\prime} \mathrm{E}\end{array}$ & 117 & 2 & 3 & 5 & $\begin{array}{l}\text { Open stream surrounded by moist- } \\
\text { deciduous forest, inactive paddy- } \\
\text { fields, and scrubland }\end{array}$ \\
\hline & 26.xi.2012 & Kalambe, Udgiri & $\begin{array}{l}17.082583^{\prime} \mathrm{N}, \\
73.816056^{\prime} \mathrm{E}\end{array}$ & 932 & 1 & 0 & 1 & $\begin{array}{l}\text { Open stream surrounded by moist } \\
\text { deciduous forest and scrubland }\end{array}$ \\
\hline & 27.xi.2012 & Vakoli, Amba & $\begin{array}{l}\text { 16.963583' } \mathrm{N}, \\
73.847111^{\prime} \mathrm{E}\end{array}$ & 594 & 1 & 1 & 2 & $\begin{array}{l}\text { Open stream passing through two } \\
\text { agricultural fields (sugarcane and } \\
\text { banana) }\end{array}$ \\
\hline & 7.i.2013 & Amboli Dam & $\begin{array}{l}15.994667 ' \mathrm{~N}, \\
74.04825^{\prime} \mathrm{E}\end{array}$ & 730 & 1 & 0 & 1 & $\begin{array}{l}\text { Closed stream surrounded by } \\
\text { scrubland }\end{array}$ \\
\hline $\begin{array}{l}\text { Hylaeothemis indica } \\
\text { Fraser, } 1946\end{array}$ & 1.vii.2012 & Bahe, Satara & $\begin{array}{l}\text { 17.308417' N, } \\
73.805658^{\prime} \mathrm{E}\end{array}$ & 940 & 1 & 0 & 1 & $\begin{array}{l}\text { Closed stream passing through } \\
\text { moist-deciduous forest }\end{array}$ \\
\hline \multirow{2}{*}{$\begin{array}{l}\text { Onychogomphus } \\
\text { nilgiriensis Fraser } \\
1922\end{array}$} & 27.x.2012 & $\begin{array}{l}\text { Parpoli Stream 2, } \\
\text { Amboli }\end{array}$ & $\begin{array}{l}15.946028 ' \mathrm{~N}, \\
73.973194 ' \mathrm{E}\end{array}$ & 95 & 1 & 0 & 1 & $\begin{array}{l}\text { Open stream surrounded by moist- } \\
\text { and dry-deciduous forest }\end{array}$ \\
\hline & 29.x.2012 & Verle, Amboli & $\begin{array}{l}15.987639^{\prime} \mathrm{N}, \\
73.970472 \mathrm{E}\end{array}$ & 117 & 1 & 0 & 1 & $\begin{array}{l}\text { Open stream surrounded by moist- } \\
\text { deciduous forest, inactive paddy- } \\
\text { fields and scrubland }\end{array}$ \\
\hline $\begin{array}{l}\text { Heliogomphus } \\
\text { promelas (Selys 1873) }\end{array}$ & 1.vii.2012 & Bahe, Satara & $\begin{array}{l}17.308417 ' \mathrm{~N} \\
73.805658^{\prime} \mathrm{E}\end{array}$ & 940 & 1 & 0 & 1 & $\begin{array}{l}\text { Closed stream surrounded by } \\
\text { moist-deciduous forest }\end{array}$ \\
\hline
\end{tabular}

with black stripes. A single female was sighted at Tanali forest-beat on a 120×10 m transect. The species was also sighted at Amboli, Parpoli and Verle (Table 1). Stream 2 of Parpoli Village showed dense population of the species. Seventeen individuals including sixteen males and one female were recorded on a 50×10 m transect. A male that was hand-picked showed 17 ante-nodal nervures in fore-wings and 29-33 post-nodal nervures in fore-wings.

iv. Pseudagrion indicum Fraser, 1924 (Coenagrionidae): Two male specimens, two mating pairs and a female specimen were sighted at Amboli and
Verle respectively (Table 1 , Image $1 F$ ). The species was also sighted at Vakoli and Kalambe villages. The male specimen was black in color marked with blue. Eyes were with a dark brown cap, greenish laterally and ventrally. Thorax was blue marked with greenish-yellow dorsal thoracic stripes. Abdomen was dorsally matt black. S8 and S9 were blue marked with black apical ring.

v. Hylaeothemis indica Fraser, 1946 (Libellulidae): A male specimen was sighted in moist-deciduous forest of Bahe (Table 1, Image 1G). The insect was perching on dry twigs and flying over and around a stream. The insect was black marked with blue. Blue mid-dorsal thoracic 

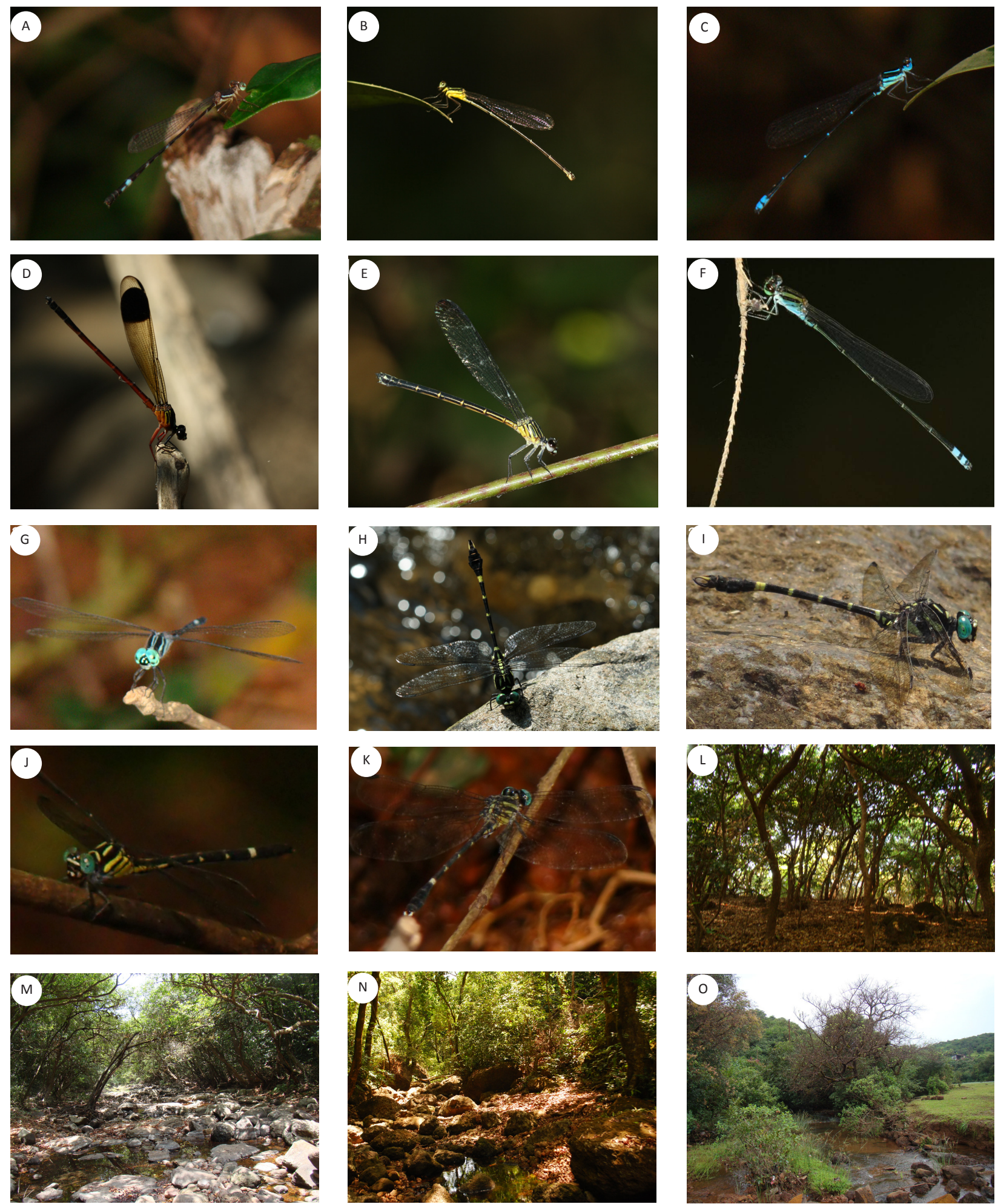

Image 1. Photographic records of species sighted. A - Protosticta hearseyi female; B - Caconeura ramburi female; C - Caconeura ramburi male; D - Eupahea fraseri male; E - Euphaea fraseri female; F - Pseudagrion indicum male; G - Hylaeothemis indica male; H, I - Onychogomphus nilgiriensis male; J, $\mathrm{K}$ - Heliogomphus promelas male; L - Semi-evergreen forest of Bahe; M - Riparian habitat of Chandel forest-beat; N - Riparian habitat of Rundiv forest-beat; 0 - Riparian habitat of Hiranyekeshi River; P - Parpoli stream 1; Q - Parpoli stream 2; R - Verle stream (next page). Photographs: A-H,J,K,O by Pankaj Koparde; I,M,L,P,Q by Prachi Mhaske; N by Ankur Patwardhan; R by Priti Bangal. 

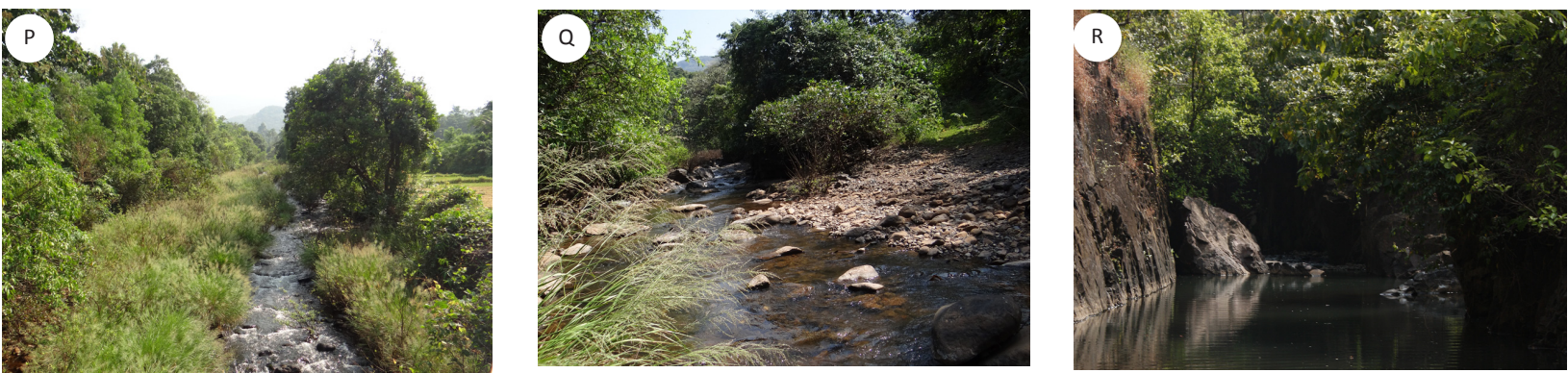

stripes, blue eyes, black legs, and blue stripes on black abdomen were few of the field characters which the insect showed.

vi. Onychogomphus nilgiriensis (Fraser, 1922) (Gomphidae): A single male specimen was sighted at Parpoli and Verle respectively (Table 1, Image $1 \mathrm{H}, \mathrm{I}$ ). The insect was found to be perching on rocks and foraging over and around the stream. Greenish-blue eyes, black abdomen marked with yellow, claw shaped anal appendages, black legs, and characteristic thoracic markings were primary determinants of the species level identification.

vii. Heliogomphus promelas (Selys, 1873) (Gomphidae): A single male specimen was sighted in moist-deciduous forest of Bahe (Table 1, Images $1 \mathrm{~J}, \mathrm{~K}$ ). The insect was foraging over and around a stream and occasionally perching on twigs. The insect was black marked with yellow. The S7 was with a broad basal yellow ring, covering approximately one third of the segment (Image $1 \mathrm{~K}$ ), which is the key to the species. This character separates it from $\mathrm{H}$. kalarensis, another Western Ghat endemic belonging to the same genus. All abdominal segments were black in color marked with yellow basal rings except for S8-S10. Eyes were bottle green in color. Frons was marked with a pale yellow horizontal stripe (Image 1J). Superior anal appendages were pale yellow and of diagnostic lyre shaped.

\section{Discussion and Conclusions}

The present study recorded 64 species from WGM covering around $62 \%$ of Odonata fauna of the state (Tiple 2012; Kulkarni et al. 2012), and adding four species to the checklist of the state. The study does not necessarily provide a checklist of the region as the sampling was opportunistic and does not adequately cover the seasonal and climatic variation shown by species assemblages. However, during this preliminary survey, we encountered new distributional records for seven Odonata species, out of which four species are new records for Maharashtra State. Four species out of these seven are Data Deficient (IUCN 2014). The prime reason behind this categorization is lack of recent information. This may be due to inadequate or lack of sampling by experts in regions (IUCN 2014), where these species are endemic. Moreover, relatively low number of scientific studies exploring Odonata fauna of northern Western Ghats of India might have created knowledge gap in our understanding of geographical distribution of these species.

Members of Platystictidae, Platycnemididae and Euphaeidae are restricted to closed canopy forested streams, streams with dense riparian vegetation, and/ or forested landscape (Subramanian 2005; Subramanian et al. 2008). More than $70 \%$ species belonging to these families that occur in India are endemic to Western Ghats (Subramanian 2007). P. hearseyi, a Western Ghats endemic species (Subramanian 2007), is known from Nilgiri, Annamalai and Travancore (Fraser 1933); Kerala (Emiliyamma et al. 2005); southwestern region of Karnataka (Subramanian et al. 2008) and Goa (Rangnekar et al. 2010). According to Tiple (2012), Protosticta gravely Laidlaw, 1915 which represents Protosticta genus has been recorded from Maharashtra, but not $P$. hearseyi. Our sighting location falls approximately $195 \mathrm{~km}$ (Google Inc. 2013) north from hitherto known northern most sighting location by Rangnekar et al. (2010). The measured abdominal size of the $P$. hearseyi male specimen (Table 2) was more than the one (30-35 mm) given by Fraser (1933). The post-nodal index provided by Fraser (1933) was smaller than the observed. This might be due to individual variation, and instrumental measurement variation or accuracy differences. According to Subramanian (2007), C. ramburi is a Western Ghats endemic species. The species is known from Western Ghats south of Uttarakannada District of Karnataka (Subramanian 2005), Goa (Rangnekar \& Naik 2014), and from some parts of Eastern Ghats (Nair 2011, Das et al. 2012). The species has been recently recorded from Pench National Park and Achanakmar-Amarkantak Biosphere Reserve of Madhya-Pradesh (Tiple \& Chandra 
Table 2. Morphometry of Protosticta hearseyi, Caconeura ramburi and Euphaea fraseri. All measurements in $\mathrm{mm}$.

\begin{tabular}{|l|c|c|c|c|c|}
\hline Species & Sex & Abdomen & $\begin{array}{c}\text { Fore- } \\
\text { wing }\end{array}$ & $\begin{array}{c}\text { Hind- } \\
\text { wing }\end{array}$ & Thorax \\
\hline Protosticta hearseyi & Male & 36.64 & 21.53 & 21.42 & 3.16 \\
\hline Caconeura ramburi & Female & 40.72 & 28.00 & 28.80 & 6.01 \\
\hline Euphaea fraseri & Male & 34.34 & 30.48 & 27.74 & 6.01 \\
\hline
\end{tabular}

2013) and from Vidarbha region of Maharashtra i.e., north-east Maharashtra (Tiple et al. 2013). Given recent records of the species on a wider scale, it can be said that the species may not be a Western Ghats endemic; but a wide-spread and under-explored species. E. fraseri is endemic to Western Ghats (Kakkasery 2011a). The northernmost records of the species in the Western Ghats include Savri Waterfalls, Dudhsagar, Paytale, Sada, Cotigao and Derode localities of Goa (Rangnekar et al. 2010); Kali River, Uttarakannada, Karnataka (Yadav et al. 2008); southwestern Karnataka (Subramanian et al. 2008). There are formal records of E. fraseri from Phansad WS, Raigad, Maharashtra (DragonflyIndia 2013; K.A. Subramanian 2013 pers. comm.) which is further north to STR. Given this potential distribution, it can be speculated that $E$. fraseri might be continuously distributed across WGM, perhaps till northern tip of WGM. P. indicum, a species endemic to Western Ghats (Subramanian 2005, 2007), is known from Nilgiris, Tamil Nadu; Kodagu and Chikmagalur, Karnataka (Subramanian 2005) and Darode locality of Goa (Rangnekar et al. 2010). Kulkarni \& Subramanian (2013) quote the species' presence at Tamhini Ghat, Pune, Maharashtra based on a single specimen. The species has also been recorded from eastern region of Bangladesh (Chowdhury \& Mohiuddin 2011). The record from Bangladesh is doubtful as the species was seen only once during 19942000 and it might be a wrong taxonomic identification. This suggests that rigorous sampling is needed to delimit distributional ranges of species, especially if they are endemic to a specific area or region.

Libellulidae and Gomphidae are well-distributed Anisopteran members across Indian subcontinent, with few species restricted to Western Ghats and/or northeast India (Fraser 1934, 1936; Subramanian 2005). Two species belonging to Libellulidae and eighteen species belonging to Gomphidae are known to be endemic to Western Ghats (Subramanian 2007). Many researchers have quoted Hylaeothemis indica as Fruhstorfer's Junglewatcher Hylaeothemis fruhstorferi Karsch (1889), creating confusion in distributional records. The former species is known to occur in India (Dow 2009a), whereas the latter one is found in Sri Lanka (Dow 2009b). H. indica is widespread across Indian subcontinent (Dow 2009a). It is known from the Western Ghats (Subramanian 2005); Nilgiri Hills, Wynaad, Annaimallai Hills, Coorg and Travancore (Fraser 1946); Ujani Wetland Reserve, Maharashtra (Kulkarni \& Prasad 2002); Kolhapur district, Maharashtra (Sathe \& Bhusnar 2010); Sada and Paytale, Goa (Rangnekar et al. 2010); and Arunachal Pradesh (Lahiri 1985). H. indica is known to breed in the seepages from marshes along the banks of mountain streams at altitude above 610m (Fraser 1936). Record by Kulkarni \& Prasad (2002) from Ujani wetland might be doubtful given the habitat requirements of the species. Lahiri (1985) record might most probably be $H$. gardeneri which is known from Himalaya (Fraser 1936), and Uttaranchal and Arunachal Pradesh (Subramanian \& Dow 2010). O. nilgiriensis is a Western Ghats endemic species (Subramanian 2007) and is known only from southern Western Ghats, the northern-most range being Dharmastala, Dakshinkannada, Karnataka (Subramanian $2005,2011)$. Although the known flight season of the species is April-June (Subramanian 2009), we recorded the species in the month of October, which may be due to bioclimatic variations. H. promelas, a Near Threatened species (Kakkasery 2011b), is known from Tamil Nadu, Kerala and Karnataka (Fraser 1934), Goa (Rangnekar et al. 2010) and Orissa (Nair 2011). The categorization of the species under threatened category is due to the fact that the species is rare and known from eight locations across Western Ghats till date, only three of them being the recent records (Kakkasery 2011b). According to Nair 2011, the peak flight period of the species is known to be only four months in monsoon (May-June and AugustSeptember). The generally mountainous, undulating terrain of Western Ghats becomes unapproachable during these months, limiting the sampling. This might be one of the reasons behind lack of knowledge on distribution of the species.

All the new records of species were found associated with closed forested streams. Within a larger landscape, stream connectivity generally allows dispersal of odonates, spreading them across the landscape. Habitat fragmentation, water pollution and diversion of water can be seen as main causal agents restricting the movement of Odonata larvae, delimiting the distribution of adults. A review by Subramanian et al. (2011) points agricultural pollution and urban and industrial development as major threats to Odonata fauna of Western Ghats. As northern Western Ghats are already highly patchy in terms of forest cover, further fragmentation is harmful for Odonata population to survive. This calls for conservation of 
closed forested streams and micro-habitats supporting such systems. All four new records for Maharashtra, has already been recorded from Goa (Rangnekar et al. 2010; Rangnekar \& Naik 2014) suggesting that the current species distribution knowledge is restricted because of lack of surveys in WGM. Amboli, which is at the southern tip of Maharashtra and in continuity with forests of Goa is supposed to have similar species composition as that of Goa. However, we recorded only E. Fraseri and O. nilgiriensis at Amboli. It is highly likely that $P$. hearseyi and $H$. promelas as well as other endemic species recorded from Goa might be present at Amboli, which we failed to detect due to opportunistic sampling. Current tourism pressure on closed forested streams of Amboli and nearby areas is high and can be detrimental to habitat sensitive species. Closed forested localities of STR are hotspots for endemic Odonata fauna. H. promelas, C. ramburi. P. hearseyi were observed at Bahe locality that lies in corridor zone of STR, joining Koyna WS and Chandoli NP. The forests at Bahe village and nearby areas which are listed in buffer area of STR, are under high pressure of forest felling due to anthropogenic pressure. E. fraseri, C. ramburi, $P$. indicum were observed in Amboli and STR, suggesting that closed forested areas with streams between STR and Amboli, such as Radhanagari WS and reserved forests in Sahyadri-Konkan corridor might be supporting these species. The published and informal records of $E$. fraseri across WGM suggest that the species might be present in forests of Mahabaleshwar and Tamhini, which also have semi-evergreen and evergreen forest patches remaining. Having said this, data obtained systematically on micro-habitat correlates, species assemblages and occupancy of climatic space by them may provide much more realistic insights into distribution of these species.

More number of systematic studies in north-west and central-west Maharashtra and in Western Ghats of Gujarat are likely to shed light on actual distribution of Western Ghats endemic odonates. The species records presented in this paper suggest that even opportunistic records of crepuscular and enigmatic species are useful in understanding distributional ranges, potential areas of species' presence, and species' biology in general, especially when the species recorded are underexplored.

\section{References}

Aland, S.R., K.A. Subramanian, A.B. Mamlayya \& G.P. Bhawane (2012). Diversity of odonates (Insecta: Odonata) in Amba reserve forest, Maharashtra, India. Bioinfolet 9(3): 254-256.

Andrew, R.J., K.A. Subramaniam \& A.D. Tiple (2008). Common Odonates of Central India. In: E-book for "The 18th International Symposium of Odonatology". Hislop College, Nagpur, India, 55pp.
Asia-dragonfly (2014). Online database accessible at http://asiadragonfly.net/. Accessed on 4 February 2014.

Chowdhury, S.H. \& M. Mohiuddin (2011). A check-list of the Odonata from the eastern region of Bangladesh with some taxonomic notes. University Journal of Zoology, Rajshahi University 30: 61-66; http://dx.doi.org/10.3329/ujzru.v30i0.10755

Córdoba-Aguilar, A. (ed.). (2008). Dragonflies and Damselflies: Model Organisms for Ecological and Evolutionary Research. Oxford University Press, New York, USA, 303pp.

Das, K.S.A., K.A. Subramanian, K.G. Emiliyamma, M.J. Palot \& K.A. Nishadh (2013). Range extension and larval habitat of Lyriothemis tricolor Ris, 1919 (Odonata: Anisoptera: Libellulidae) from southern Western Ghats, India. Journal of Threatened Taxa 5(17): 5237-5346; http://dx.doi.org/10.11609/JoTT.03716.5237-46

Das, S.K., R.A. Ahmed, S.K. Sajan, N. Dash, P. Sahoo, P. Mohanta, H.K. Sahu, S.D. Raut \& S.K. Dutta (2012). Diversity, distribution and species composition of Odonates in buffer areas of Similipal Tiger Reserve, Eastern Ghat, India. Academic Journal of Entomology 5(1): 54-61.

Dow, R.A. (2009a). Hylaeothemis indica. In: IUCN 2013. IUCN Red List of Threatened Species. Version 2013.2. <www.iucnredlist.org>. Downloaded on 15 January 2014.

Dow, R.A. (2009b). Hylaeothemis fruhstorferi. In: IUCN 2013. IUCN Red List of Threatened Species. Version 2013.2. <www.iucnredlist.org>. Downloaded on 15 January 2014.

DragonflyIndia (2013). Online database accessible at https://www. facebook.com/photo. php?fbid=10151784127621705\&set=gm.579 785755404305\&type=1/. Accessed on 10 February 2014.

DragonflyIndia (2014). Online database accessible at http://www. facebook.com/groups/dragonflyindia/. Accessed on 4 January 2014.

Emiliyamma, K.G. (2005). On the Odonata (Insecta) fauna of Kottayam district, Kerala, India. Zoos' Print Journal 20(12): 2108-2110; http:// dx.doi.org/10.11609/jott.zpj.1338.2108-10

Emiliyamma, K.G. \& C. Radhakrishnan (2000). Odonata (Insecta) of Parambikulam wildlife sanctuary, Kerala, India. Records of the Zoological Survey of India 98(1): 157-167.

Emiliyamma, K.G. \& C. Radhakrishnan (2002). Additions to the Odonata (Insecta) of Thiruvananthapuram District, Kerala. Zoos' Print Journal 17(10): 914-917; http://dx.doi.org/10.11609/jott. zpj.17.10.914-7

Emiliyamma, K.G., C. Radhakrishnan \& M.J. Palot (2005). Pictorial Handbook on Common Dragonflies and Damselflies of Kerala. Zoological Survey of India, New Delhi, India, 67pp.

Emiliyamma, K.G., M.J. Palot \& C. Radhakrishnan (2012) Microgomphus souteri Fraser, a new addition to the Odonata (Insecta) fauna of Kerala, southern India. Journal of Threatened Taxa 4(6): 2667-2669; http://dx.doi.org/10.11609/jott.o2885.26679

Emiliyamma, K.G., M.J. Palot, C. Radhakrishnan \& V. Balakrishnan (2013). Lyriothemis acigastra: a new addition to the odonata fauna of Peninsular India. TAPROBANICA: The Journal of Asian Biodiversity 5(1): 73-74; http://dx.doi.org/10.4038/tapro.v5i1.5672

Fraser, F.C. (1924). A survey of the Odonate (Dragonfly) fauna of Western India with special remarks on the genera Macromia and Idionyx and descriptions of thirty new species with appendices I \& II. Records of the Indian Museum 26(5): 423-522.

Fraser, F.C. (1932). Additions to the survey of odonate fauna of Western India, with descriptions of nine new species. Records of the Indian Museum 32: 443-474.

Fraser, F.C. (1933). The Fauna of British India including Ceylon and Burma. Odonata - Vol. I. Taylor and Francis Ltd., London, 439pp.

Fraser, F.C. (1934). The Fauna of British India including Ceylon and Burma. Odonata - Vol. II. Taylor and Francis Ltd., London, 430pp.

Fraser, F.C. (1936). The Fauna of British India including Ceylon and Burma. Odonata - Vol. III. Taylor and Francis Ltd., London, 485pp.

Fraser, F.C. (1946). Hylaeothemis indica, a new species of oriental Libelluline (Order Odonata). In: Proceedings of the Royal Entomological Society of London. Series B, Taxonomy Blackwell Publishing Ltd., London. 15(7-8): 97-100; http://dx.doi. 
org/10.1111/j.1365-3113.1946.tb00831.x

Hijmans, R.J., L. Guarino, A. Jarvis, R. O'Brien, P. Mathur, C. Bussink, M. Cruz, I. Barrantes \& E. Rojas (2005). Diva-GIS version 5.2 Manual. Available at http://www.diva-gis.org/docs/. Accessed on 8 October 2012.

IUCN (2014). The IUCN red list of threatened species. Version 2013.2. Online database accessible at http://www.iucnredlist.org/. Accessed on 4 January 2014.

Kakkasery, F. (2011a). Euphaea fraseri. In: IUCN 2013. IUCN Red List of Threatened Species. Version 2013.2. <www.iucnredlist.org> Downloaded on 15 January 2014.

Kakkasery, F. (2011b). Heliogomphus promelas. In: IUCN 2013. IUCN Red List of Threatened Species. Version 2013.2. <www.iucnredlist. org>. Downloaded on 15 January 2014.

Kiran, C.G. \& D. Raju (2013). Dragonflies and Damselflies of Kerala (Keralathile Thumbikal). Tropical Institute of Ecological Sciences, Kerala, India, 324pp.

Kulkarni P.P. \& S.S. Talmale (2008). Insecta: Odonata. Fauna of Goa. State Fauna Series, Zoological Survey of India 16: 173-194.

Kulkarni, A. \& K.A. Subramanian (2013). Habitat and seasonal distribution of Odonata (Insecta) of Mula and Mutha river basins, Maharashtra, India. Journal of Threatened Taxa 5(7): 4084-4095; http://dx.doi.org/10.11609/jott.03253.4084-95

Kulkarni, P.P. \& M. Prasad (2002). Fauna of Ujani Wetland (Maharashtra): Insecta: Odonata, pp. 91-104 In: Wetland Ecosystem Series - 3. Zoological Survey of India, Calcutta, India.

Kulkarni, P.P., R. Babu, S. Talmale, C. Sinha \& S.B. Mondal (2012). Insecta: Odonata. In: Fauna of Maharashtra: State Fauna Series. Zoological Survey of India, Kolkata, India, 20(2): 397-428.

Lahiri, A. R. (1985). Fauna of Namdapha: Arunachal Pradesh (Insecta: Odonata). Records of Zoological Survey of India (Special Issue) 82: 61-67

Myers, N., R.A. Mittermeier, C.G. Mittermeier, G.A. Da Fonseca \& J. Kent (2000). Biodiversity hotspots for conservation priorities. Nature 403(6772): 853-858.

Nair, M.V. (2011). Dragonflies \& Damselflies of Orissa and Eastern India. Wildlife Organisation, Forest \& Environment Department, Government of Orissa, Bhubaneshwar, 254pp.

Prasad, M. (1995). On a collection of odonata from Goa. Fraseria (N.S.) 2(1/2): 7-8.

Radhakrishnan, C. \& K.G. Emiliyamma (2003). Odonata (Insecta) of Kerala: A systematic database. Advancements in Insect Biodiversity (2003): 195-224.

Rangnekar, P. \& R. Naik (2014). Further additions to the Odonata (Insecta) fauna of Goa, India. Journal of Threatened Taxa 6(3): 55855589; http://dx.doi.org/10.11609/jott.o3641.5585-9

Rangnekar, P., M. Borkar \& O. Dharwadkar (2010). Additions to the Odonata (Insecta) of Goa. Journal of Threatened Taxa 2(4): 805814; http://dx.doi.org/10.11609/jott.02286.805-14
Sathe, T.V. \& A.R. Bhusnar (2010). Biodiversity of Mosquitovorus dragonflies (Order: Odonata) from Kolhapur District including Western Ghats. Biological Forum-an International Journal 2(2): 38-41.

Subramanian, K.A., P. Rangnekar \& R. Naik (2013). Idionyx (Odonata: Corduliidae) of the Western Ghats with a description of a new species. Zootaxa 3652(2): 277-288; http://dx.doi.org/10.11646/ zootaxa.3652.2.5

Subramanian, K.A. \& K.G. Sivaramakrishnan (2005). Habitat and microhabitat distribution of stream insect communities of the Western Ghats. Current Science 89(6): 976-987.

Subramanian, K.A. \& R.A. Dow (2010). Hylaeothemis gardeneri. In: IUCN 2013. IUCN Red List of Threatened Species. Version 2013.2. <www.iucnredlist.org>. Downloaded on 15 January 2014.

Subramanian, K.A. (2005). Dragonflies and Damselflies of Peninsular India - A Field Guide. Series Ed. Madhav Gadgil. Published under the Project Lifescape Series. Indian Academy of Sciences, Banglore, India, 118pp.

Subramanian, K.A. (2007). Endemic odonates of the Western Ghats: habitat distribution and conservation, pp. 257-271. In: Tyagi, B.K. (ed.). Odonata: Biology of Dragonflies. Scientific Publishers, Jodhpur, India.

Subramanian, K.A. (2009). A Checklist of Odonata (Insecta) of India. Zoological Survey of India, Pune, India, 36pp.

Subramanian, K.A. (2011). Onychogomphus nilgiriensis. In: IUCN 2013. IUCN Red List of Threatened Species. Version 2013.2. <www. iucnredlist.org>. Downloaded on 15 January 2014.

Subramanian, K.A., F. Kakkassery \& M.V. Nair (2011). The status and distribution of dragonflies and damselflies (Odonata) of the Western Ghats, pp. 63-72. Molur, S., K.G. Smith, B.A. Daniel \& W.R.T. Darwall (comp.). The Status and Distribution of Freshwater Biodversity in the Western Ghats, India. IUCN, Cambridge, UK and Glad, Switzerland and Zoo Outreach Organization, Coimbatore, India.

Subramanian, K.A., S. Ali \& T.V. Ramchandra (2008). Odonata as indicators of riparian ecosystem health a case study from south western Karnataka, India. Fraseria (N.S.) 7: 83-95.

Tiple, A. (2012). Dragonflies and Damselflies (Insecta-Odonata) from Nagpur city environs in Vidharba, together with other records from Maharashtra, India. Colemania 27: 1-12.

Tiple, A. \& K. Chandra (2013). Dragonflies and Damselflies (Insecta, Odonata) of Madhya Pradesh and Chhattisgarh States, Central India. Journal Care4Nature 1(1): 3-11.

Tiple, A.D., R.J. Andrew, K.A. Subramanian \& S.S. Talmale (2013). Odonata of Vidarbha region, Maharashtra state, central India. Odonatologica 42(3): 237-245

Yadav, A.S., K.V. Gururaja, B. Karthik, G.R. Rao, V. Mukri, S.M.D. Chandran \& T.V. Ramchandra (2008). Ecological Status of Kali River Flood Plain. ENVIS Technical Report.CES, IISc, Bangalore, India, 42pp. 
Annexure 1. List of species sighted during the survey.

\begin{tabular}{|c|c|c|c|c|}
\hline & Scientific Name & Common Name & IUCN Status & $\mathbf{E}$ \\
\hline & Suborder: Anisoptera & & & \\
\hline & Family: Aeshnidae & & & \\
\hline 1 & Anax guttatus (Burmeister, 1839) & Blue-tailed Green-Darner & LC & \\
\hline 2 & Anax immaculifrons Rambur, 1842 & Blue Darner & LC & \\
\hline 3 & Gynacantha bayadera Selys, 1891 & Parakeet Darner & LC & \\
\hline \multirow[t]{2}{*}{4} & Gynacantha dravida Lieftinck,1960 & Brown Darner & DD & \\
\hline & Family: Gomphidae & & & \\
\hline 5 & Heliogomphus promelas (Selys,1873) & Indian Lyretail** & NT & $x$ \\
\hline 6 & Onychogomphus nilgiriensis (Fraser, 1922) & Nilgiri Clawtail** & LC & $x$ \\
\hline \multirow[t]{2}{*}{7} & Paragomphus lineatus (Selys,1850) & Common Hooktail & LC & \\
\hline & Family: Libellulidae & & & \\
\hline 8 & Acisoma panorpoides Rambur, 1842 & Trumpet Tail & LC & \\
\hline 9 & Brachythemis contaminata (Fabricius, 1793) & Ditch Jewel & LC & \\
\hline 10 & Bradinopyga geminata (Rambur, 1842) & Granite Ghost & LC & \\
\hline 11 & Cratilia lineata Foerster, 1903 & Emerald-banded Skimmer & LC & \\
\hline 12 & Crocothemis servilia (Drury, 1770) & Ruddy Marsh-Skimmer & LC & \\
\hline 13 & Diplacodes trivialis (Rambur,1842) & Ground Skimmer & LC & \\
\hline 14 & Hylaeothemis indica Fraser,1946 & Blue Hawklet* & DD & \\
\hline 15 & Indothemis carnatica (Fabricius, 1798) & Blue Ground-Skimmer & NT & \\
\hline 16 & Lathrecista asiatica (Fabricius, 1798) & Asiatic Blood-Tail & LC & \\
\hline 17 & Neurothemis fulvia (Drury, 1773) & Fulvous Forest-Skimmer & LC & \\
\hline 18 & Neurothemis intermedia (Rambur, 1842) & Paddyfield Parasole & LC & \\
\hline 19 & Neurothemis tullia (Drury, 1773) & Pied Paddy-Skimmer & LC & \\
\hline 20 & Orthetrum chrysis (Selys, 1891) & Brown-backed Red Marsh-Hawk & LC & \\
\hline 21 & Orthetrum glaucum (Brauer, 1865) & Blue Marsh-Hawk & LC & \\
\hline 22 & Orthetrum luzonicum (Brauer, 1868) & Tricolored Marsh-Hawk & LC & \\
\hline 23 & Orthetrum pruinosum (Burmeister,1839) & Crimson-tailed Marsh-Hawk & LC & \\
\hline 24 & Orthetrum Sabina (Drury, 1770) & Green Marsh-Hawk & LC & \\
\hline 25 & Orthetrum taeniolatum (Schneider,1845) & Small Skimmer & NA & \\
\hline 26 & Palpopleura sexmaculata (Fabricius, 1787) & Blue-tailed Yellow Skimmer & LC & \\
\hline 27 & Pantala flavescens (Fabricius, 1798) & Wandering Glider & LC & \\
\hline 28 & Potamarcha congener (Rambur, 1842) & Yellow-tailed Ashy Skimmer & LC & \\
\hline 29 & Rhodothemis rufa (Rambur, 1842) & Rufous Marsh Glider & LC & \\
\hline 30 & Tholymis tillarga (Fabricius, 1798) & Coral-tailed Cloud-Wing & LC & \\
\hline 31 & Tramea basilaris (Palisot de Beauvois, 1805) & Red Marsh-Trotter & LC & \\
\hline 32 & Tramea limbata (Desjardins,1832) & Black Marsh-Trotter & LC & \\
\hline 33 & Trithemis aurora (Burmeister, 1839) & Crimson Marsh-Glider & LC & \\
\hline 34 & Trithemis festiva (Rambur, 1842) & Black Stream-Glider & LC & \\
\hline 35 & Trithemis kirbyi Selys, 1891 & Scarlet Rock-Glider & LC & \\
\hline 36 & Trithemis pallidinervis (Kirby, 1889) & Long-legged Marsh-Hawk & LC & \\
\hline \multirow[t]{2}{*}{37} & Zygonyx iris Selys,1869 & Iridescent Stream-Glider & LC & \\
\hline & Family: Macromiidae & & & \\
\hline 38 & Epophthalmia vittata Burmeister,1839 & Common Torrent-Hawk & LC & \\
\hline
\end{tabular}




\begin{tabular}{|c|c|c|c|c|}
\hline & Scientific Name & Common Name & IUCN Status & E \\
\hline & Suborder: Zygoptera & & & \\
\hline & Family: Calopterygidae & & & \\
\hline 39 & Vestalis apicalis Selys, 1873 & Black-tipped Forest-Glory & $\mathrm{LC}$ & \\
\hline \multirow[t]{2}{*}{40} & Vestalis gracilis (Rambur, 1842) & Clear-winged Forest-Glory & LC & \\
\hline & Family: Chlorocyphidae & & & \\
\hline 41 & Libellago lineata (Burmeister, 1839) & River Heliodor & $\mathrm{LC}$ & \\
\hline \multirow[t]{2}{*}{42} & Rhinocypha bisignata Hagen in Selys, 1853 & Stream Ruby & LC & \\
\hline & Family: Coenagrionidae & & & \\
\hline 43 & Aciagrion hisopa (Selys, 1876) & Violet-striped Slender- Dartlet & LC & \\
\hline 44 & Aciagrion occidentale Laidlaw, 1919 & Green-striped Slender- Dartlet & LC & \\
\hline 45 & Aciagrion pallidum Selys, 1891 & Pale Slender-Dartlet & NA & \\
\hline 46 & Agriocnemis pygmaea (Rambur, 1842) & Pigmy Dartlet & NA & \\
\hline 47 & Agriocnemis splendidissima Laidlaw,1919 & Splendid Dartlet & NA & \\
\hline 48 & Ceriagrion coromandelianum (Fabricius, 1798) & Coromandel Marsh-Dart & LC & \\
\hline 49 & Ceriagrion olivaceum Laidlaw, 1914 & Rusty Marsh-Dart & LC & \\
\hline 50 & Ischnura aurora (Brauer, 1865) & Golden Dartlet & LC & \\
\hline 51 & Ischnura senegalensis (Rambur, 1842) & Senegal Golden Dartlet & LC & \\
\hline 52 & Pseudagrion decorum (Rambur, 1842) & Three-striped Blue-Dart & LC & \\
\hline 53 & Pseudagrion indicum Fraser, 1924 & Yellow-striped Blue-Dart* & DD & $x$ \\
\hline 54 & Pseudagrion microcephalum (Rambur, 1842) & Blue Grass-Dart & LC & \\
\hline \multirow[t]{2}{*}{55} & Pseudagrion rubriceps Selys, 1876 & Saffron-faced Blue-Dart & LC & \\
\hline & Family: Euphaeidae & & & \\
\hline \multirow[t]{2}{*}{56} & Euphaea fraseri (Laidlaw,1920) & Malabar Torrent-Dart** & LC & $x$ \\
\hline & Family: Lestidae & & & \\
\hline 57 & Lestes elatus Hagen in Selys, 1862 & Emerald Spreadwing & LC & \\
\hline \multirow[t]{2}{*}{58} & Lestes umbrinus Selys, 1891 & Dusky Spreadwing & LC & \\
\hline & Family: Platycnemididae & & & \\
\hline 59 & Copera marginipes (Rambur, 1842) & Yellow Bush-Dart & LC & \\
\hline \multirow[t]{2}{*}{60} & Copera vittata Selys,1863 & Blue Bush-Dart & LC & \\
\hline & Family: Platystictidae & & & \\
\hline \multirow[t]{2}{*}{61} & Protosticta hearseyi Fraser,1922 & $N A^{* *}$ & DD & $x$ \\
\hline & Family: Platycnemididae & & & \\
\hline 62 & Caconeura ramburi (Fraser,1922) & Coorg Bambootail* & DD & $\mathrm{x}$ \\
\hline 63 & Disparoneura quadrimaculata (Rambur,1842) & Black-winged Bambootail & LC & \\
\hline 64 & Prodasineura verticalis (Selys,1860) & Black Bambootail & LC & \\
\hline
\end{tabular}

E - Endemic to Western Ghats (Subramanian 2005); LC - Least concern; DD - Data deficient; NT - Near threatened; NA - Not available; X - True;

* new spatial record; **new record for Maharashtra State. 